\title{
RESPON PEMBERIAN ZPT AUKSIN dan BERBAGAI MEDIA TANAM TERHADAP BIBIT KELAPA SAWIT(Elaeis guineensis Jacq) di PEMBIBITAN AWAL (Pre Nursary)
}

\author{
RAZALI \\ Prodi Budidaya Perkebunan, Fakultas Pertanian dan Peternakan, Tjuk Nyak Dhien, email: razalicool81@gmail.com \\ Hasby Agung Prabowo Siregar \\ Prodi Budidaya Perkebunan, Fakultas Pertanian dan Peternakan, Tjuk Nyak Dhien, email:
}

\begin{abstract}
Abstrak
Penelitian ini bertujuan untuk mengkaji Pengaruh Pemberian ZPT Auksin dan Berbagai Media Tanam Terhadap Bibit Kelapa Sawit (Elaeis guineensis Jacq) Di Pembibitan Awal (PRE NURSERY). Tujuan jangka pendek dari penelitian ini adalah dapat diketahui ZPT Akusin yang dapat mempengaruhi pertumbuhan kelapa sawit dan Media Tanam yang dapat membantu peningkatan jasa drenik di pembibitan. Metode yang digunakan dalam penelitian ini adalah Rancangan Acak Kelompok (RAK) Faktorial terdiri dari dua factor yaitu: Faktor pertama: Pemberian Ragam Media Tanam 3 taraf $: \mathrm{M}_{0}=$ Top Soil $100 \%, \mathrm{M}_{1}=$ Top Soil 50\%, Blotong Tebu 50\%. $\mathrm{M}_{2}=$ Blotong Tebu 70\%, Top Soil 30\%.Faktor kedua : Pemberian ZPT Auksin 4 taraf : $\mathrm{A}_{0}=\operatorname{tanpa} \mathrm{ZPT}$ Auksin, $\mathrm{A}_{1}=\mathrm{ZPT}$ Auksin $10 \mathrm{ml} / \mathrm{liter}$ air, $\mathrm{A}_{2}=$ ZPT Auksin $15 \mathrm{ml} /$ liter air, $\mathrm{A}_{3}=\mathrm{ZPT}$ Auksin $20 \mathrm{ml} /$ liter air. Ragam media tanam yang diberikan adalah media tanam yang sesuai dengan perlakuan yakni $\mathrm{M}_{0}=$ Top Soil $100 \% . \mathrm{M}_{1}=$ Top Soil $50 \%$, Blotong Tebu $50 \% . \mathrm{M}_{2}=$ Blotong Tebu 70\%, Top Soil 30\%. Blotong Tebu yang diberikan adalah Blotong yang telah siap pakai. Pemberian ZPT Auksin ke media tanaman topsoil sesuai dengan perlakuan yakni $\mathrm{A}_{0}=$ tanpa $\mathrm{ZPT}$ Auksin, $A_{1}=$ ZPT Auksin $10 \mathrm{ml} /$ liter air, $\mathrm{A}_{2}=\mathrm{ZPT}$ Auksin $15 \mathrm{ml} / \mathrm{liter}$ air, $\mathrm{A}_{3}=\mathrm{ZPT}$ Auksin $20 \mathrm{ml} / \mathrm{liter}$ air. Pemberian ZPT Auksin diberikan satu bulan setelah tanam (5 MST) atau 2 kali penyiraman yakni 5 MST dan 7 MST. Pemberian perlakuan denganragam media tanamtop soil $100 \%$, top soil 50\%, Blotong Tebu 50\% dan Blotong Tebu $70 \%$, top soil $30 \%$, memberikan hasil yang tidak nyata pada semua parameter pengamatan tinggi tanaman luas daun, diameter batang umur serta bobot basah tanaman dan berat kering.Pemberian perlakuan dengan $\mathrm{A}_{0}=$ tanpa ZPT Auksin, ZPT Auksin $10 \mathrm{ml} /$ liter air, ZPT Auksin $15 \mathrm{ml} /$ liter air dan ZPT Auksin 20 $\mathrm{ml} /$ liter air tidak memberikan pengaruh yang nyata pada semua parameter pengamatan tinggi tanaman, luas daun, diameter batang umur serta bobot basah tanaman dan berat kering tanaman umur Interaksi ZPT Auksin dan Berbagai Media Tanam terhadap pertumbuhan bibit tanaman kelapa sawit (Elaeis guineensis Jacq) di pembibitan awal tidak memberikan pengaruh yang nyata pada semua paremeter pengamatan yakni tinggi tanaman, luas daun, diameter batang umur serta bobot basah tanaman dan berat kering tanaman.
\end{abstract}

Kata Kunci: ZPT Auksin, Top Soil, Blotong Tebu, Pembibitan, Kelapa Sawit, Media Tanam.

\section{PENDAHULUAN}

Kelapa sawit adalah tanaman penghasil minyak paling tinggi produktivitasnya. Dari kelapa sawit bukan hanya diperoleh minyak untuk keperluan pangan tetapi dapat dibuat untuk keperluan industri lainnya. Keunggulan kelapa sawit cukup banyak, biaya produksi murah, produksi per hektar tinggi (4-6 ton minyak / ha / tahun) dan umur ekonomi panjang (25-30 tahun) (Lubis, 1992).

Menurut BPS. (2013), luas areal pertanaman sawit di Indonesia dari tahun 1995 sampai tahun 2012 sebesar 5.406,9000 Hektar, dengan produksi CPO sebesar 14.788.270 ton.

Dalam usaha membudidayakan kelapa sawit masalah pertama yang dihadapi oleh pengusaha atau petani yang bersangkutan adalah tentang pengadaan bibit. Kualitas bibit sangat menentukan produksi akhir komoditas in. (Sianturi, 1992). Perawatan bibit yang baik di pembibitan awal dan pembibitan utama melalui dosis pemupukan yang tepat merupakan salah satu upaya untuk mencapai hasil yang optimal dalam pengembangan budidaya kelapa sawit (Santi dan Goenadi, 2008). Berdasarkan penelitian di Sumatera Utara, unsur-unsur hara yang berpengaruh positif terhadap pertumbuhan dan produksi kelapa sawit adalah nitrogen $(\mathrm{N})$, fosfor $(\mathrm{P})$, kalium $(\mathrm{K})$, magnesium $(\mathrm{Mg})$, serta unsur hara mikro boron (B) (Sastrosayono, 2008).

\section{METODE}

Waktu dan Tempat Penelitian

Penelitian dilaksanakan pada Bulan Juli 2016Oktober 2016 di lahan masyarakat Jalan Jamin Ginting Gg. Pancasila, Binjai.

\section{Bahan dan Alat}

Bahan:

Bahan yang digunakan dalam penelitian ini adalah media tanah top soil, blotong tebu, baby polybag $5 \mathrm{~kg}$ ukuran lebar $25 \mathrm{~cm}$ ketebalan $0,15 \mathrm{~mm}$, benih tanaman kelapa sawit D x P Kelurahan Marihat Siantar, ZPT 
Auksin.

Alat:

Alat-alat yang digunakan adalah paranet $80 \%$, cangkul, gembor, label nama, timbangan analitik, alat tulis, plastik, ember, meteran, kalkulator, pompa air.

\section{Model Rancangan}

Penelitian dilakukan dengan menggunakan rancangan acak kelompok (RAK) faktorial dengan dua taraf yaitu:

Faktor pertama: Pemberian Ragam Media Tanam Padi 3 taraf:

$\mathrm{M}_{0} \quad=$ Top Soil $100 \%$

$\mathrm{M}_{1} \quad=$ Top Soil $50 \%$, Blotong Tebu $50 \%$

$\mathrm{M}_{2} \quad=$ Blotong Tebu $70 \%$, Top soil $30 \%$

Faktor kedua: ZPT Auksin 4 taraf:

$\mathrm{A}_{0} \quad=$ tanpa ZPT Auksin

$\mathrm{A}_{1} \quad=$ ZPT Auksin $10 \mathrm{ml} /$ liter air

$\mathrm{A}_{2} \quad=$ ZPT Auksin $15 \mathrm{ml} /$ liter air

$\mathrm{A}_{3} \quad=$ ZPT Auksin $20 \mathrm{ml} /$ liter air

Perubahan yang diamati adalah:

Tinggi tanaman $(\mathrm{cm})$, luas daun, diameter batang, berat basah tanaman, berat kering tanaman.

\section{HASIL DAN PEMBAHASAN}

\section{Tinggi Tanaman $(\mathrm{cm})$}

Berdasarkan data tinggi tanaman dan analisis sidik ragam tanaman kelapa sawit $(\mathrm{cm})$, diketahui bahwa perlakuan ragam media tanam dan ZPT Auksin memberikan hasil yang tidak nyata pada semua pengamatan umur 5 MST, 7 MST, 9 MST, dan 11 MST. Demikian juga pada interaksi perlakuan ragam media tanam dan ZPT Auksin pada tanaman kelapa sawit umut 11 MST disajikan pada tabel 2.

Pada tabel 2, dapat dilihat bahwa interaksi perlakuan ragam media tanam dan pupuk ZPT Auksin terhadap tinggi tanaman umur 11 MST saling berbeda tidak nyata antar tiap taraf perlakuan. Pemberian ZPT Auksin $\left(\mathrm{A}_{1}\right)$ memiliki tinggi tanaman tertinggi yaitu $18,32 \mathrm{~cm}$, sedangkan $\mathrm{M}_{2}$ memiliki tinggi tanaman tertinggi yaitu $18,43 \mathrm{~cm}$.

\section{Luas Daun $\left(\mathrm{cm}^{2}\right)$}

Berdasarkan data luas daun dan analisis sidik ragam tanaman kelapa sawit $(\mathrm{cm})$, diketahui bahwa perlakuan ragam media tanam dan ZPT Auksin memberikan hasil yang tidak nyata pada semua pengamatan umur 5 MST, dan 11 MST. Demikian juga pada interaksi perlakuan ragam media tanam dan ZPT Auksin pada tanaman kelapa sawit umut 11 MST disajikan pada tabel 3 .

Pada tabel 3, dapat dilihat bahwa interaksi perlakuan ragam media tanam dan pupuk ZPT Auksin terhadap luas daun umur 11 MST saling berbeda tidak nyata antar tiap taraf perlakuan. Pemberian ZPT Auksin $\left(\mathrm{A}_{2}\right)$ memiliki luas daun tertinggi yaitu $77,51 \mathrm{~cm}^{2}$, sedangkan $\left(\mathrm{M}_{2}\right)$ memiliki luas daun tertinggi yaitu 78,00 $\mathrm{cm}^{2}$. Interaksi perlakuan media taman dan ZPT Auksin menunjukan berbeda tidak nyata pada seluruh kombinasi perlakuan walaupun menunjukan berbeda tidak nyata perlakuan $\mathrm{M}_{2} \mathrm{~A}_{2}$ memberikan luas daun tertinggi 80,62 $\mathrm{cm}^{2}$.

\section{Diameter Batang ( $\mathrm{mm})$}

Hasil pengamatan diameter batang $(\mathrm{mm})$ tanaman kelapa sawit umur 11 MST saling berbeda tidak nyata antar tiap taraf perlakuan. Pemberian ZPT Auksin $\left(\mathrm{A}_{0}\right)$ memiliki diameter batang tertinggi yaitu $6,73 \mathrm{~mm}$, sedangkan $\left(\mathrm{M}_{1}\right)$ memiliki luas daun tertinggi yaitu $6,81 \mathrm{~mm}$. Interaksi perlakuan media taman dan ZPT Auksin menunjukan berbeda tidak nyata pada seluruh kombinasi perlakuan walaupun menunjukan berbeda tidak nyata perlakuan $\mathrm{M}_{2} \mathrm{~A}_{3}$ memberikan diameter batang tertinggi $7,12 \mathrm{~mm}$.

\section{Berat Basah Tanaman (gr)}

Hasil pengamatan berat basah tanaman kelapa sawit umur 11 MST saling berbeda tidak nyata antar tiap taraf perlakuan. Pemberian ZPT Auksin $\left(\mathrm{A}_{1}\right)$ memiliki berat basah tertinggi yaitu $12,11 \mathrm{gr}$, sedangkan $\left(\mathrm{M}_{2}\right)$ memiliki luas daun tertinggi yaitu 12,42 gr. Interaksi perlakuan media taman dan ZPT Auksin menunjukan berbeda tidak nyata pada seluruh kombinasi perlakuan walaupun menunjukan berbeda tidak nyata perlakuan $\mathrm{M}_{2} \mathrm{~A}_{1}$ memberikan berat tertinggi 15,00 gr.

\section{Berat Kering Tanaman}

Hasil pengamatan berat kering tanaman kelapa sawit umur $11 \mathrm{MST}$ saling berbeda tidak nyata antar tiap taraf perlakuan. Pemberian ZPT Auksin $\left(\mathrm{A}_{1}\right)$ memiliki berat kering tertinggi yaitu 4,69 gr, sedangkan $\left(\mathrm{M}_{2}\right)$ memiliki berat kering tertinggi yaitu 4,80 gr. Interaksi perlakuan media taman dan ZPT Auksin menunjukan berbeda tidak nyata pada seluruh kombinasi perlakuan walaupun menunjukan berbeda tidak nyata perlakuan $\mathrm{M}_{2} \mathrm{~A}_{1}$ memberikan berat kering tertinggi 6,10 gr.

\section{Pembahasan}

\section{Pengaruh pemberian ZPT Auksin terhadap pertumbuhan vegetatif bibit tanaman kelapa sawit (Elaeis guineensis Jacq) di pembibitan awal}

Dari hasil penelitian dapat dilihat bahwa pemberian perlakuan dengan ZPT Auksin memberikan hasil yang nyata pada parameter pengamatan tinggi tanaman umur 5 MST dan tidak nyata pada umur 7 MST, 9 MST dan 11 MST, luas daun tidak nyata pada umur 5 MST dan 11 MST, diameter batang tidak nyata pada umur 5 MST, 7 MST, 9 MST dan 11 MST, serta berat basah tanaman dan berat kering tanaman tidak nyata pada umur $11 \mathrm{MST}$. Hasil yang nyata pada tinggi tanaman umur 5 MST hal ini disebabkan Akusin memacu proses terbentuknya akar serta pertumbuhan akar dengan lebih baik. Hal ini dapat dilihat pada pendapat Aninim³ , (2011) dan Riyadi, (2014), ), mengatakan bahwa Auksin banyak ditemukan pada akar, ujung batang, dan bunga. Fungsi auksin dalam pertumbuhan tanaman adalah sebagai pengatur pembesaran sel dan memicu pemanjangan sel di 
daerah belakang ujung meristem. Auksin berperan penting dalam pertumbuhan, sehingga dapat digunakan untuk memacu kecepatan pertumbuhan bibit tanaman pada budidaya yang dilakukan secara intensif. Dari hasil yang tidak nyata pada tinggi tanaman pada umur 7 MST, 9 MST dan 11 MST, luas daun tidak nyata pada umur 5 MST dan 11 MST, diameter batang tidak nyata pada umur 5 MST, 7 MST, 9 MST dan 11 MST, serta berat basah tanaman dan berat kering tanaman tidak nyata pada umur 11 MST hal ini dikarenakan respon auksin yang kurang memberikan pengaruh signifikan terhadap tanaman kelapa sawit. Menurut Anonim ${ }^{3}$, (2011) Auksin disintesis di pucuk batang dekat meristem pucuk, jaringan muda (misal daun muda) dan terutama bergerak arah ke bawah batang (polar), sehingga terjadi perbedaan kadar auksin di pucuk batang dan di akar. Aktivitasnya meliputi perangsangan dan penghambatan pertumbuhan, tergantung pada konsentrasi auksinnya. Jaringan yang berbeda memberikan respon yang berbeda pula terhadap kadar auksin yang dapat merangsang atau menghambat pertumbuhan tanaman. Karena kadar auksin memberikan hasil yang tidak signifikan terhadap tanaman kelapa sawit.

2. Pengaruh ragam media tanam terhadap pertumbuhan vegetatif bibit tanamam kelapa sawit (Elaeis guineensis Jacq) di pembibitan awal

Dari hasil penelitian dapat dilihat bahwa pemberian perlakuan dengan ragam media tanam top soil $100 \%$, top soil $50 \%$ + blotong tebu $50 \%$, top soil $30 \%+$ blotong tebu $70 \%$ memberikan hasil yang nyata pada pengamatan tinggi tanaman umur 5 MST dan 9 MST, luas daun umur 5 MST dan tidak nyata pada pengamatan tinggi tanaman umur 7 MST dan 11 MST, luas daun umur 11 MST, diameter batang umur 5 MST, 7 MST, 9 MST dan 11 MST, berat basan dan berat kering umur 11 MST. Hal ini disebabkan karena ragam media tanam tidak mampu mempengaruhi pertumbuhan tanaman bibit kelapa sawit tersebut, pada lampiran analisis sebelum tanam dapat dilihat bahwa unsur hara yang terdapat pada media tanam tersebut sangat rendah, Pada lampiran analisa media tanam umur 11 MST terjadi penambahan atau kenaikan unsur hara dalam media tanam akan tetapi tidak dapat mempengaruhi pertumbuhan dan porositas tanah. Menurut Mulyani, 2002., apabila porositas tanah baik, maka keseimbangan turgor tanaman menjadi baik hal ini diperlukan untuk proses fotosintesis. Hasil fotosintesis akan banyak dimanfaatkan oleh tanaman untuk pertumbuhannya. Hal ini juga diperkuat oleh Leiwakabessy, 1998. mengatakan bahwa pertumbuhan dan perkembangan tanaman sangat dipengaruhi oleh unsur hara yang tersedia pertumbuhan akan maksimum jika unsur hara yang tersedia dalam keadaa optimum dan seimbang. Gardner, $d k k$ (1991) menyatakan bahwa unsur hara yang tersedia pada konsentrasi tertentu dapat meningkatkan pembentukan protein, karbohidrat dan lemak yang dibentuk tanaman dalam proses fotosintesis dan asimilasi digunakan oleh tanaman untuk pembentukan dan perkembangan sel baru. Menurut Syarif (1986), mengemukakan bahwa untuk tanaman tahunan, penambahan jumlah daun dan luas daun dapat membutuhkan unsur hara yang seimbang dan berlanjut dalam waktu yang cukup lama. Pada tanaman tahunan atau tanaman berumur panjang lamanya daun untuk membuka sempurna setelah keluar dari tunasnya membutuhkan waktu kira kira satu bulan. Jumlah daun yang terbentuk dipengaruhi oleh tinggi tanaman, dimana semakin tinggi tanaman maka jumlah yang muncul akan semakin bertambah karna adanya tunas-tunas baru yang akhirnya tunas ini berkembang menjadi daun.

\section{Interaksi pemberian ZPT Auksin dan ragam media tanam terhadap pertumbuhan vegetatif bibit tanaman kelapa sawit (Elaeis guineensis Jacq) di pembibitan awal}

Dari hasil penelitian dapat dilihat bahwa interaksi pemberian ZPT Auksin dan ragam media tanam terhadap pertumbuhan vegetative bibit kelapa sawit (Elaeis guineensis Jacq) di pembibitan awal tidak memberikan pengaruh yang nyata pada semua parameter pengamatan yakni tinggi tanaman pada umur 5 MST, 7 MST, 9 MST dan 11 MST, luas daun umur 5 MST dan 11 MST, diameter batang umur 5 MST, 7 MST, 9 MST dan 11 MST, berat basah dan berat kering umur 11 MST. Hal ini disebabkan karena pemberian ZPT Auksin dan ragam media tanam belum mampu mempengaruhi pola aktivitas fisiologi tanaman secara interval, walaupun diantara perlakuan yang diuji telah mampu mendukung pertumbuhan tanaman secara fisiologi.

Adapun hal lain yang menyebabkan tidak adanya pengaruh yang nyata terhadap seluruh parameter yang diamati diduga interaksi kedua perlakuan kurang saling mendukung satu sama lainnya, sehingga efeknya akar tanaman tidak respon dan ini sesuai dengan pendapat Nyakpa, dkk (1986), yang menyatakan bahwa pertumbuhan tanaman yang baik dapat tercapai bila faktor yang mempengaruhi pertumbuhan berimbang dan menguntungkan.

Dalam hal lain faktor luar dari tanaman itu sendiri kurang mendukung aktivitas dari kedua perlakuan, sebab kombinasi dari kedua perlakuan tertentu tidak selamanya akan memberikan pengaruh yang baik pada tanaman. Ada kalanya kombinasi tersebut akan mendorong pertumbuhan, menghambat pertumbuhan atau sama sekali tidak memberikan respon terhadap pertumbuhan dan perkembangan tanaman.

\section{PENUTUP}

\section{Kesimpulan}

1. Pemberian ZPT Auksin secara analisa statistik tidak memberikan pengaruh yang nyata terhadap seluruh parameter. Namun, secara 
visual memberikan pengaruh terhadap tinggi tanaman umur 11 MST dengan tinggi $18,32 \mathrm{~cm}$.

2. Pemberian Media Tanam secara analisa statistik tidak memberikan pengaruh yang nyata terhadap seluruh parameter. Namun, secara visual memberikan pengaruh terhadap tinggi tanaman umur 11 MST dengan tinggi 18,43 cm.

3. Interaksi antara pemberian ZPT Auksin dan Media Tanam secara analisa statistik tidak memberikan pengaruh yang nyata terhadap seluruh parameter.

\section{Saran}

Dalam budidaya tanaman kelapa sawit pemberian ZPT Auksin dan Ragam Media Tanam perlu dilakukan penelitian lanjutan dalam hal pemberian dosis ZPT Auksin dan Ragam media tanam yang optimum yang tepat untuk mendapatkan hasil produksi tanaman yang baik.

\section{DAFTAR PUSTAKA}

Anonimus. 2013. Pemanfaatan Blotong Tebu berbagai Media Tanam dan Pupuk.

http//warasfarm.wordpres.com. diakses tanggal 28 Maret 2016.

Anonim ${ }^{1}$. 2013. Hormon Tumbuhan (Auksin, Giberelin, Sitokinin, Etilen, Asam Absisat). http://zonabawah.blogspot.com. Diakses Pada Tanggal 6 Juli 2014.

Anonim ${ }^{2} .2013$ http://id.answers.yahoo.com. Apa Fungsi Auksin, Sitokinin, Giberelin, Etilen, Asam Absisat. Diakses Pada Tanggal 12 Juni 2014.

Anonim ${ }^{3}$. 2011. Pengaruh dan Fungsi Hormon. http://henvikaekaade.blogspot .com. Diakses Pada Tanggal 9 Agustus 2014.

Badan Pusat Statistik. 2013. Luas Lahan dan Produksi Tanaman Kelapa Sawit. http://bps.go.id. Akses tanggal 15 Mei 2013.

Chan, F. dan E.L. Tobing, 1982. Pemupukan Bibit Kelapa Sawit. PedomanTeknis. Buletin Pusat Penelitian Perkebunan Marihat, Pematang Siantar, Sumut

Dartius. 1995. Fisiologi Tanaman. USU. Medan.

Fauzi, Y., Y. E. Widyastuti, I. Satyawibawa, R. Hartono. 2014. Kelapa Sawit : Budidaya, Pemanfaatan Hasil dan Limbah, Analisis Usaha dan Pemasaran. Penebar Swadaya. Jakarta. Hal. 1163.

Gardner, F.P.R.B. Pearce dan R.L. Mitchell. 1991. Fisiologi Tanaman, UI - Press : Jakarta

Gomez, K. A. dan A. A. Gomez. 2007. Prosedur Statistika untuk Penelitian Pertanian. Terjemahan : Sjamsudin, E dan J. S. Baharsyah. UI-Press.

Hadisuwito, S. 2008. Membuat Pupuk Kompos Cair. PT Agromedia Pustaka. Jakarta. 50 hal
Hajrah, S. 1997. Pengaruh Macam Media Tumbuh Dalam Teknik Hidroponik Terhadap Pertumbuhan dan Hasil Tanaman Paprika. (Skripsi), Fakultas Pertanian, Unuversitas Mataram. 139 $\mathrm{h}$

Hartley, C.W.S., 1977. The Oil Palm. Second Edition, Longmans and CO.Ltd, London. 